\title{
THE EVOLUTION OF THE COMMUNITY DEVELOPMENT INDUSTRY
}

\section{A Practitioner's Perspective}

Mark McDermott

The evolution of the affordable housing and neighborhood development industry in Cleveland intertwine over a span of three decades with my own career. This story could be told by any one of dozens of other housing and community development professionals that worked in Cleveland following the principles of equity planning: to provide more choices for those who have few, as set out in the Cleveland Planning Commission's Cleveland Policy Planning Report (1975).

In his introduction, Norman Krumholz posits the importance of equity planning activity outside of official planning agencies, including at neighborhoodbased community development organizations. This chapter describes such activity as it took place in Cleveland. More specifically, it describes the convergence of the broader social justice movement of the period and the work of Cleveland's equity planners. The work described called forth new iterations and forms of equity planning by both formal and informal institutions. Often, it was the nonprofit community-based organizations described, not official planning agencies, who provided the leadership, the blocking, and the tackling needed to keep the field open to equity principles.

Four key actors played a foundational role in having Cleveland's planning and community development industries make a shift to greater equity for the poor. Cleveland Mayor Carl B. Stokes set the stage by bringing an overall progressive agenda to the city. Norm Krumholz's planning staff then brought what could be possible into focus through its pronouncement of equity planning. The Catholic Commission on Community Action under the Greater Cleveland Diocese enabled 
the professionalization of community organizing in Cleveland by developing a pipeline of candidates and training and funding them. Finally, local foundations adopted the work as important to the future of the city and provided reliable, multiyear funding.

Thus, the Cleveland of this period provided a rich environment for experimentation with the principles of the 1975 Cleveland Policy Planning Report and the implementation of policies and practices built on these principles. It was a time when individual careers in planning, housing, and community development evolved in conjunction with the growth and evolution of the field.

In 1980, when I began my career, neither the HOME Program nor the LowIncome Housing Tax Credit (LIHTC) existed. There were few community development corporations (CDCs). The cadre of skilled nonprofit development professionals was small and mostly self-taught. It was a time for big ideas, incredible entrepreneurism, and future building.

This chapter covers five phases of this CDC work and my career in Cleveland:

1. Strong community organizing (1980-1984);

2. New systems capacity and resources (1984-1988);

3. Growth of the affordable housing industry (1988-1998);

4. Maturing of systems and resources (1998-2008);

5. Toward an integrated agenda (2008-Present).

Over the course of this story I describe the five key lessons I've learned by looking at real and measurable outcomes over the past thirty-five years.

1. An engaged, dual focus on place and people can overcome any particular politics. Focusing on only one of these factors leads to limited results that often set back particular equity agendas.

2. Policy that results in change always results from some type of community organizing-sometimes through conflict, sometimes through collaboration, usually through some combination of the two.

3. Money always matters in achieving change, and how and where it flows is sometimes more important than how much flows.

4. Racism and poverty are intimately intertwined—one cannot legitimately deal with one without dealing with the other.

5. Affordable housing, while a real estate product and now an industry, is an effective platform that enables low-income residents to bring about positive change in their own lives. 


\section{Strong Community Organizing, 1980-1984}

Cleveland in 1980 was a confusing time for community organizing. George V. Voinovich, a moderate Republican, had just replaced Dennis J. Kucinich as mayor of Cleveland. Kucinich was a self-styled urban populist who garnered support from many progressives; he also alienated much of Cleveland's corporate leadership, which has been well documented (Swanstrom 1985). Yet Kucinich also alienated the growing community organizing movement in Cleveland. His cabinet often refused to meet with neighborhood leaders, and this conflict lead to the mayor banning the leading neighborhood organizations from city hall. Mayor Voinovich, on the other hand, was more conservative and certainly more tied to the corporate community, yet his administration had a strong commitment to the neighborhoods and was generally supportive of neighborhood initiatives.

It was against this background that in 1980, fresh out of college, I was hired as a community organizer by a neighborhood-based community organization. At that time there were eight strong neighborhood-based community organizations in Cleveland, supported by the Catholic Commission on Community Action of the Catholic Diocese of Cleveland (Cunningham 2007, Yin 1998). The commission provided hiring assistance, training, back office support, and a level of political cover. In addition, the organizations were all members of the National People's Action (NPA) of Chicago. As a national membership organization, the NPA was able to provide both training and networking that helped community organizing in Cleveland reach a high level of effectiveness in both tactics and community engagement. Locally, a citywide network of Cleveland's community organizations brought staff and community leadership together from across the city, creating a racially diverse coalition that fought together on a range of neighborhood disinvestment, city service, and poverty issues unlike any time since.

Specifically, they focused on three issues: bank redlining, strategic and equitable expenditure of city resources, and the formation of Cleveland's initial CDCs. The confrontational strategies of Saul Alinsky were used extensively, and their efforts have had lasting impact on Cleveland neighborhoods.

The issue of mortgage and lending redlining by financial institutions across the country is well documented. It was no different in Cleveland than in other older, lower-income, and racially changing cities. At a time when almost all lending institutions were local, it was very common for entire urban neighborhoods to be excluded by implicit policy and explicit practice. With Congress's passage of the Community Reinvestment Act (CRA) in 1979, and the related Home Mortgage Disclosure Act (HMDA) in 1975, community activists were provided with effective tools to confront local redlining. All of the community organizations in 
the city participated in the newly formed community reinvestment coalition; this coalition quickly became the premier citywide issue coalition while creating the deepest and most enduring outcomes. The coalition combined a variety of strategies over five years, including filing CRA challenges with the Federal Reserve Bank; holding community meetings with banks to create consumer, housing, and commercial investment plans; and, when necessary, disrupting annual shareholder meetings with signs, whistles, and chants. The results were mostly positive and truly set the stage for the investments in CDC-sponsored projects that would take place over the next thirty years. Several banks established their own community development divisions or set up their own CDCs, which exist to this day. And the city of Cleveland adopted one of the first community reinvestment policies in the country, using the leverage of municipal investments to force each bank to set a full range of housing, consumer, and commercial investment goals for Cleveland neighborhoods. The cooperative nature of bank and CDC relationships of the past thirty years has only been possible because of the success of this earlier coalition organizing.

Another long-term organizing success resulted from a similar coalition that focused on the strategic and equitable expenditure of Cleveland's Community Development Block Grant (CDBG) funds. In the early 1980s, the city used its CDBG funds in an unfocused way, primarily for a wide variety of improvements including sidewalks and street repair, while ignoring the new, more communitybased CDCs with a stronger housing focus. The citywide coalition pressured the Voinovich administration to expand its investments in affordable housing specifically and neighborhoods in general, by analyzing prior year investments, holding coalition-sponsored meetings in each neighborhood, taking over public hearings, and marching on city hall. This organizing resulted in the adoption of a more strategic and equitable decision-making process by the administration and city council, increased investments in affordable housing, and increased block grant funding for CDCs. Again, it is due to this organizing work of thirty years ago that Cleveland has led the country in support for progressive CDCs, which continues to the present day.

The third long-term outcome for the organizers was the formation of more progressive, community-based, housing-focused CDCs. Prior to the 1980s, there existed a set of what were called local development corporations (LDCs). These organizations were funded by the city, focused on neighborhood commercial development, and had limited engagement in the community. More concerning, very few of these LDCs were located in the predominantly African American neighborhoods of the city's east side. The LDCs lost out when the communitybased organizations sponsored or formed another competing set of CDCsfunded by foundations, focused on housing development, intimately engaged 
with the community, and active in all of Cleveland's neighborhoods, both black and white. These included the Bank on Buckeye, Broadway Area Housing Coalition, Near West Housing Corporation, and several others. These were the groups that partnered with the city, banks, and foundations to create a new affordable housing industry in Cleveland, and they were soon to form the Cleveland Housing Network $(\mathrm{CHN})$, changing the trajectory of many of Cleveland's neighborhoods.

One final historical note on community organizing in Cleveland. As documented in other publications, the era of strong advocacy-based and communitybased organizing in Cleveland ended by the mid-1980s. These advocacy-based organizations maintained confrontational tactics as they expanded their agendas to include issues that had additional corporate targets: the banks, utilities, and energy companies. This direction eventually led to the substantial defunding of these organizations by local foundations, a move which fairly quickly led to the demise of most of the organizations. But most of these advocacy organizations spun off CDCs whose development agendas did not include social change, and these CDCs have survived to the present.

\section{New Systems Capacity and Resources, 1984-1988}

In 1984 I left community organizing and joined the staff at the Center for Neighborhood Development (CND) at the Levin College of Urban Affairs at Cleveland State University (Simon 2009). Originally funded by two local foundations, CND was set up to provide technical assistance and training to the nascent CDCs and to put them on a sustainable path. Over the next few decades, CND would offer a sterling example of the possibilities of effective neighborhood outreach for a university-based, technical assistance organization.

This period in Cleveland was really about proving the case for CDCs. The city, banks, and foundations were asking questions about the long-term viability of CDCs, the potential impact of investment in CDCs, and whether CDCs in Cleveland could translate meaningful engagement with community residents into meaningful improvements. CND helped provide several outcomes that were crucial to assuring the various funders that the CDCs were well worth their confidence and support.

For one, CND and its partners developed basic training sessions on real estate development, weatherization, and creative financing before such trainings were common in the industry. This training and technical assistance was instrumental in building the expertise of CDC staff, evolving in sophistication as the develop- 
ment models and financing became more complex. CND also provided technical assistance to newer citywide coalitions that succeeded the neighborhood organizing coalitions, including neighborhood safety, weatherization, and development of strategies for dealing with the CRA. These new coalitions used a more collaborative model; yet, when it seemed appropriate, coalition members were not shy to threaten or actually use confrontational approaches based on past successes. This coalition activity resulted in finding new allies and gaining substantial new resources at both the state and city levels. State money flowed for home weatherization programs, and new foundation and city funding was made available for housing development through CDCs.

It was during this period that $\mathrm{CHN}$ was founded with the support of CND, the Famicos Foundation, and the Enterprise Foundation (Krumholz 1997, McQuarrie and Krumholz 2011). (The Enterprise Foundation later changed its name to Enterprise Community Partners; it is referred to as Enterprise in this chapter.) The founding organizations of CHN wanted to build on Famicos's small-scale but successful lease-purchase program for low-income buyers. The Famicos model relied solely on CDBG financing to rehabilitate vacant properties and lease them to poor families, while Famicos retained ownership of all properties. CHN believed it could improve the Famicos model and bring it to scale.

It can reasonably be argued that $\mathrm{CHN}$ might not have been formed and certainly would have looked very different if not for the capacity that had been developed at the other neighborhood-based CDCs and their interest in expanding the Famicos financial model. The fact is that five other CDCs from across townthe other founding members of $\mathrm{CHN}$ - had strong staff expertise and engaged local boards. A strong network between them enabled those CDCs to stand on par with Famicos when expressing their goal to have an equal and participatory role in forming CHN. Most of the executive directors of the five CDCs had in fact been community organizers from across the city, and the informal network they created was a direct outgrowth of the earlier community organizing coalition. The story of CHN's creation embodied the trust that had developed among very different communities and helped to launch this next phase of improving Cleveland's neighborhoods. In fact, trust is a vital component of the entire neighborhood development story in Cleveland. CHN's board structure, which to this day has representatives of all the affiliated CDCs, also helped build trust and cooperation.

CND also provided support to some of these early CDCs as they developed radically new financing models for affordable housing. For example, Near West Housing Corporation and Union Miles Development Corporation both piloted an unproven approach to bring private equity based on accelerated depreciation tax incentives into multifamily deals. This was prior to the establishment of the 
LIHTC. This same tool was eventually used by CHN to finance its first two leasepurchase rehab deals. This new ability to leverage the CDBG funds enabled CHN to create more units and spread those units across the six different neighborhoods. This financing tool, along with CHN's equitable board structure, encouraged and at times even forced CDCs from across the city to work together rather than compete, thus making $\mathrm{CHN}$ a key player in the development of affordable housing in Cleveland.

CHN's success has been remarkable. By 2015, CHN was a membership organization with twenty-three CDCs working in partnership to develop affordable housing with an emphasis on homeownership for the poor. It had built over two thousand such homes. It may be best known for its innovative use of the LIHTC to redevelop Cleveland's deteriorated inner-city neighborhoods. Its scattered-site lease-purchase program is the oldest and largest in the country. CHN is effectively Cleveland's affordable housing provider outside of the local housing authority (Cuyahoga Metropolitan Housing Authority, or CMHA).

The third important outcome of this period was the formation of Neighborhood Progress, Inc. (NPI) as Cleveland's community development intermediary. (NPI is now known as Cleveland Neighborhood Progress, but NPI is used in this chapter.) NPI was formed principally by the Cleveland Foundation and the George Gund Foundation with the participation of Cleveland Tomorrow, a private civic organization made up of chief executive officers of the largest companies in the Cleveland area. It was formed primarily to standardize and coordinate funding of the city's developing CDCs. No other outcome of this period has had longer term or deeper impact on the CDC industry in Cleveland. NPI now coordinates four different streams of private funding from the Gund, Cleveland, Mandel, and Enterprise Foundations. These four philanthropies have funded Cleveland's CDCs via NPI for two decades, an extraordinarily long-term indication of confidence.

The close relationship between NPI and Enterprise is particularly noteworthy. Since Enterprise entered the Cleveland market, NPI has been its primary partner. Enterprise has found that NPI keeps its work grounded and serves as an effective local community development intermediary by providing strategic funding, technical assistance, and thought leadership. Enterprise has passed millions of dollars of Housing and Urban Development (HUD) Section IV capacity-building dollars to NPI because they believe the investment is strategic and effective.

CND also provided support to the CDCs and CHN as they influenced the final structure of NPI. CND staff served as a bridge between the creators of NPI and the CDCs, many of whom were distrustful of the agenda NPI was created to serve. NPI would certainly have been formed without CND's work; the founda- 
tions and the corporate sector were clear on this, but the structure may not have explicitly included CDC representation. There was also a concern on the part of neighborhood advocates that NPI was simply co-opting the CDCs to support a foundation/corporate agenda. CND helped to work through those concerns due to the trust and respect CND's staff enjoyed from all parties.

\section{Growth of the Affordable Housing Industry: CHN and Cleveland's CDCs, 1988-1998}

In 1988 I joined CHN to start up a multifamily development initiative. As Cleveland's housing stock is predominately made up of single- and two-family homes, $\mathrm{CHN}$ had focused its efforts to increase the supply of affordable housing on redeveloping single homes using the lease-purchase model. CHN's leadership saw the need to test the feasibility of expanding this model to the city's multifamily sector. They acquired and rehabilitated ten such properties under two LIHTC deals over two years, aggregating them across multiple neighborhoods. However, because of the weak rental market at the time and the difficulty in managing these properties in the city's historic neighborhoods, they called the experiment to an end and shifted their focus back to single-family homes.

In 1990, CHN's first director moved to city hall to become Mayor Michael White's director of community development, and I took over as CHN's executive director. Over the next eight years $\mathrm{CHN}$ built on its solid track record. The successful use of the (then) new LIHTCs and the growing strength of its member CDCs allowed us to become the leading affordable housing organization in the region. In our first ten years we went from an annual production of twenty-five to over two hundred units, from fifteen to fifty staff, and from six to fifteen affiliated member CDCs.

CHN was overwhelmingly successful because it paid close attention to production, partnerships, and funders. Our partnership with the city of Cleveland was strong because we could be counted on to acquire vacant properties in virtually all city wards, rehabilitate them, and lease them to responsible tenants. This pleased both the administration and city council, so funding from the city was steady. The state housing finance agency worked to prove the LIHTC program a success. They knew they could count on CHN to produce units on time and on budget and that resulted in consistent annual credit allocations. Foundation support was consistent because of CHN's ability to focus on the real estate and on improving the neighborhoods and the lives of the residents. 
CHN's member CDCs also valued our partnership and the value created through the rehab program. This was evidenced by the growth in the number of member CDCs during this period-almost every CDC in town wanted to be a $\mathrm{CHN}$ member.

The CHN-CDC partnerships were not without problems on both sides. The primary CDC roles were property selection and property management in their neighborhoods. However, $\mathrm{CHN}$ reserved the right to decline properties for acquisition due to design shortcomings or budget limitations. Issues also arose related to the challenging nature of scattered-site rental property management. Together, $\mathrm{CHN}$ and the CDCs learned a very important lesson-property management was a business, and if the CDCs were not collecting rents and controlling expenses, they could not operate the units. Some CDCs internalized this basic rule better than others. One problem inherent to CHN's structure was that the CDCs were voting members and held a seat on CHN's board of trustees; yet, CHN might need to enforce penalties or cancel property management contracts with the same CDCs. It was a difficult but manageable balancing act.

$\mathrm{CHN}$ also provided measurable value for the community. Vacant homes were transformed into visible assets and opportunities for affordable homeownership. We supported the development of contractors from the community. Almost all were small, proprietor-owned businesses, and at any point in time probably half of the contractors used by $\mathrm{CHN}$ were minority-owned businesses.

During this time $\mathrm{CHN}$ developed the Homeward program, an acquisition-rehab program resulting in the direct sale of homes to home buyers. The addition of this program enabled $\mathrm{CHN}$ to bring both lease-purchase rental and for-sale products to neighborhoods. This allowed the CDCs to be strategic in building neighborhood real estate markets while increasing values, increasing minority homeownership, and more effectively targeting substantially all the vacant homes on a given street.

$\mathrm{CHN}$ also provided community value as it partnered with newer CDCs with limited experience in real estate development and risk management. CHN provided the capital for its lease-purchase and Homeward programs so that the CDC did not need to take on debt; $\mathrm{CHN}$ retained ownership, so all risk ultimately resided at the CHN level. This enabled newer CDCs to learn the real estate development business in a safe environment. It was not long before many of these CDCs were doing their own LIHTC deals while still participating in CHN's programs. CHN was not the only driver for this growth; NPI was also funding and supporting these CDCs, but without $\mathrm{CHN}$ the pace of growth would have been much slower.

One last note on CHN: the tension of the dual nature of the business-serving low-income residents and running a real estate business with a real bottom line- 
played itself out within CHN's staff and board and in the CDC partnerships. Some CHN staff focused on helping poor residents, while others made sure that the bottom line was healthy and fees were earned. Some staff and trustees thought the organization should operate only the lease-purchase program and not start up the Homeward program, because they believed the Homeward program to be helping the "middle class," as opposed to the poor; others believed that we needed to promote more homeownership and build up property values. Some member CDCs wanted only to operate the Homeward program in their neighborhood while others believed that each CDC ought to be serving both low-income renters and home buyers. In this case it was CHN's membership structure and the nature of the board of trustees that forced us to work together in solving these internal policy issues; it wasn't realized at the time, but both programs brought significant positive impact to the community.

By the end of this period, in the late 1990s, Cleveland had one of the most productive nonprofit housing sectors in the nation. I would argue this was due to four factors:

1. The strength of $\mathrm{CHN}$ and the CDCs due to the dynamics summarized above;

2. The ongoing commitment of the foundation community and NPI to fund the CDCs;

3. Cleveland Mayor White's focus on housing production as a key to the future of the city's neighborhoods, and the ability of his administration to effectively deliver resources; and

4. The resources brought to Cleveland by national intermediaries, Enterprise, and the Local Initiative Support Corporation (LISC).

\section{Maturing of Systems and Resources, 1998-2008}

In 1998 I left CHN to join Enterprise as the director of the Cleveland office and later became its regional director. Enterprise is a national nonprofit organization founded in 1982. It relies on contributions from individual donors, corporations, and the federal government to help rebuild low-income communities. From 1982 to 2015 it raised and invested more than $\$ 18.6$ billion in loans, grants, and equity to build or renovate about 340,000 homes in partnership with nonprofits across the country. Before turning to the Enterprise program, and why and how it added value to the local scene, let's look at some other important factors impacting the movement during this period. 
By the mid-1990s the LIHTC had become the major source of funding for affordable housing production in the country. It had proven itself as a tool around which to build other financing and gained the confidence of investors, essentially becoming a reliable commodity. In Cleveland, local investors (through Cleveland Tomorrow) became less important as Enterprise and LISC were able to draw on their national funds. Any loss in flexibility offered by local funds was offset by the reliability of national funds. With Enterprise doing the fund-raising work nationally, local community developers were freed up to do the deals and work with residents.

This maturing of the system was also reflected in the formalization of the taxcredit allocation process at the Ohio Housing Finance Agency (OHFA). Credits became easier to use, and the equity became an essential way to finance deals; therefore demand increased and competition grew. OHFA and HFAs across the country responded to these factors by making the process more formal, with clear competitive criteria. The decentralized administration of this tax-credit program to the states was and continues to be an asset of the program. The state HFAs are far more responsive to local needs and conditions than Washington, DC, could ever be. Each HFA is required to have a Qualified Action Plan to govern its allocation of credits to local organizations. When the local community is well organized, as the Cleveland community development organizations have been, it can truly influence the prioritization of strategies for credit allocation. A good example of this is OHFA's establishment of a set-aside of credits for permanent supportive housing that serves the Housing First program described below.

As the availability of LIHTC increased, for-profit developers began to enter into this segment of the affordable housing market. In Cleveland this entry of forprofits was viewed with caution by nonprofit community developers. The production capacity of the for-profits sometimes exceeded that of the nonprofits, but their connection and commitment to the community was often lacking. It became clear, however, that some in both developer camps were able to combine being effective along with being engaged as they produced housing developments that brought benefit to the community and to residents.

At the same time, it's important to point out that some Cleveland nonprofits also lacked the necessary expertise. NPI, Enterprise, and LISC helped to establish a set of organizational and performance standards and provided technical assistance to the nonprofits in meeting and exceeding these standards. Despite this assistance, there are still some low-performing CDCs.

While this is certainly not unique to Cleveland, the city does have a unique system for funding CDCs that in some cases exacerbated this problem. As CDCs became a proven and successful vehicle for community development, each Cleveland councilperson wanted one to serve their ward. In some cases, these new 
CDCs were neither effective nor accountable to the community at large. Over time, councilpersons controlled the allocation of an increasing share of the city's CDBG funds. Some CDCs stayed in business long after their ineffective business practices would have brought them to an end if it were not for the ongoing support of councilperson CDBG funds.

In Cleveland, about two-thirds of the city's CDBG funding is divided among the city's seventeen ward-based councilpersons. Each is allocated about $\$ 450,000$ a year of CDBG funds to use for "neighborhood improvement." Neighborhood improvement plans must ultimately be approved by the city's department of community development, which ensures that they comply with HUD rules and regulations. When it works well, this system of allocating funding places decisions about neighborhood improvement closer to residents, who elect their councilperson. Indeed, there are more examples of positive and long-lasting outcomes than negative, but it would be disingenuous not to point out this phenomenon in the Cleveland community development industry and to note that it can also have dysfunctional aspects.

Problems notwithstanding, on the whole, Cleveland's CDC movement has matured to become an efficient, sophisticated "industry" that is known throughout the country for its ability to provide quality, affordable housing for thousands of the city's low-income residents. By 2008, however, Cleveland, even more so than the rest of the nation, was in the midst of the foreclosure crisis and recession. The city that had been known for equity planning and its pioneering community development organizations became known as the epicenter of the foreclosure crisis. Even though homeowners and renters living in CDC-assisted housing fared much better than most, many neighborhoods were decimated. The CDCs quickly realized that providing quality affordable housing and a path to homeownership was no longer enough.

\section{Toward an Integrated Agenda, 2008-Present}

Enterprise, in partnership with funders, government, and other nonprofits, took a lead role to develop a broader, more integrated agenda that addressed issues rooted in poverty and race and created solutions with lasting value for the full community in Cleveland. The following three examples demonstrate how this agenda was implemented.

The first example is the Enterprise-led Housing First Initiative (Feran 2014). As in all major American cities, in Cleveland the number of people experiencing homelessness rose dramatically after the dismemberment of the mental health 
services and institutions begun under President Reagan. In 2002, Enterprise, in partnership with the Cleveland/Cuyahoga County Office of Homeless Services and the Sisters of Charity Foundation, brought the Housing First model to greater Cleveland. At the time, Housing First was a proven but radical solution to chronic homelessness. Housing First prioritized stable permanent housing as the solution for persons who suffered mental health and/or addiction challenges while experiencing long-term homelessness. Enterprise worked quickly to bring together the best local implementation partners-EDEN, Inc.; FrontLine Service; and CHN. By 2015, thirteen years later, the initiative has met with such successachieving a 78 percent decrease in chronic homelessness - that we now envision the possibility of ending chronic homelessness in Cuyahoga County by 2020.

Housing First works because of at least four key factors. The first was the creation of an implementation coalition that called for three lead organizations to do what they do best and trust that their partners would also perform. These organizations have a track record of using foundation and public resources effectively. The second factor was the building of a learning environment among the partners and funders-one that was based on outcomes and measurement. Third, the issue of chronic homelessness was defined as an issue that could be solved in an appeal to the hearts and minds of those in power. Fourth, political champions in city, county, and state government that truly wanted to solve the social problem were identified. The last two factors combined to prove that, while many in power choose to ignore issues of race and poverty, there are approaches that can bring the attention and resources needed to solve complex problems.

The second Enterprise-led example is the Cuyahoga Earned Income Tax Credit (EITC) Coalition begun in 2005 to encourage more widespread use of the federal tax credit that provides a much-needed income boost to Cleveland's working families. (Marr et al. 2015, Cuyahoga EITC Coalition n.d.). This initiative includes a coalition of over twenty partners and funders who deliver free tax preparation at sites across the county, bringing in refunds in 2015 that totaled over \$18 million. About one-third of the more than thirteen thousand annual consumers served are working families who claim the EITC and receive an average credit of $\$ 1,500$. They also save a typical annual tax-preparation fee of $\$ 300$. The national numbers show that the EITC is one of the most effective federal antipoverty tools. In Cuyahoga County, 20 percent of eligible families were not claiming the tax credit. The EITC Coalition has been successful in focusing resources for people experiencing poverty because, as with Housing First, it has a resultsfocused set of partners and successfully combines a focus on positive social/ economic outcomes.

The third example is the Enterprise-led Green Communities Initiative. Begun over ten years ago at the national level, Green Communities seeks to bring the 
benefits of green, healthy housing to residents of affordable housing. Green housing arose from the environmental movement and for years was an option only for those who lived in market rate developments and had upper- to middle-class incomes. Enterprise decided that more and more housing ought to be built to reduce carbon emissions, save energy, and benefit our environment, but we also asked the question, "Don't people with lower incomes deserve to benefit from lower heating bills and healthier environments?" Green Communities did just this. In less than a decade the separation between affordable housing and green housing was bridged in hundreds of states and localities around the country. This was the case both in the city of Cleveland and at the state level in Ohio. In Cleveland, Mayor Frank Jackson declared that, beginning in 2005, all new housing was to be built to meet Enterprise's Green Communities criteria. The OHFA did the same relative to all new LIHTC-financed housing. In both cases bold policymakers saw the dual benefit to the environment and to low-income residents and took action. The results have been impressive. Building to a strong green standard is now the norm in both cases; developers assume it's how things are done, and thousands of lower-income residents enjoy the same benefits as do more wealthy renters and homeowners across the state.

These are just three of many examples of how Enterprise has brought resources coupled with thought leadership, in Cleveland and across the country, to affordable housing and solutions for residents of low-income communities. The end result is increased opportunity for residents.

\section{Closing Observations}

Replicating the successes that I've outlined-increasing the strength of community organizing, producing new resources and policies, building housing and community development delivery systems, or integrating opportunity as our leading indicator-all fall back on the lessons described at the beginning of this chapter. Keep the following front and center-focus on people and place, keep community organizing central, influence how and where the money flows, realize that poverty and racism are always intertwined — and always keep affordable housing a leading strategy.

Several other closing thoughts seem appropriate thirty-five years after the start of this work, particularly in light of the results of the 2016 election.

Racial equity matters. Equity planning needs to prioritize racial equity first and addressing poverty second. The same is true for partnerships among nonprofits, foundations, and local government. As this chapter illustrates, advocates are most effective when they form coalitions and are able to use data to demonstrate that 
programs work. People of color still face a distinct disadvantage; their initial access to the ladder of opportunity begins at a lower rung than their white counterparts. To talk about providing opportunity without acknowledging this disadvantage is choosing ignorance. Good planning and the most effective programs will fail if they are based on ignorance or, worse yet, denial of racial inequity.

Housing affordability matters. We have accomplished much but we are falling further behind. Thousands of new and preserved affordable housing units have made a real difference in the lives of low-income residents. Making housing affordable and reducing costs from 50 percent to 30 percent of a family's income puts real dollars back in their pocket to pay for basic needs and to help move that family ahead. We also know that housing stability, made possible by keeping housing costs affordable, makes a difference in a family's health, education, and income. But wages have declined or remained flat, and we've lost more affordable housing than we've gained to either abandonment or rising values and marketbased rents. We need to partner with policymakers to show the value of stable, affordable housing and shift from defense to offense in making the case for more resources.

Data matters. Research informs policy, and a focus on data and impact measurement only strengthens our case. Whether this focus is on racial disparities in health, education, and income, or on the best structure for access to opportunity so that a family's income stability and status actually changes over time, we can make the case. Data is our friend but it's not cheap. Funders are increasingly requesting impact measurement, but they need to pay for it. The new "pay for success" model is a good start, but it cannot be the only way. We cannot let people of color and low-income families suffer even longer by delaying programs and policies because the data cost curve is deemed to be too expensive.

People and places matter. The challenge of focusing on both place and opportunity is a difficult one. Federal and state policy currently promotes building new affordable housing and moving voucher holders out to "high opportunity" areas. Let's do that. Let's work with the residents and stakeholders in those areas to create a compassionate environment to embrace low-income people. But funding is scarce, and we cannot abandon the vast majority of low-income families who are predominately people of color to the high-poverty and high-crime areas that are the result of public and corporate disinvestment if there is no access to these programs. We know how to do this place-based work, we know what works to improve low-income neighborhoods, and we know how to implement programs that address both people and places. What's missing are sufficient resources—-public and private—and political will. Oftentimes the simplest answer is the truth. 
Lastly, planning and community development in America could easily become irrelevant in the near future, at least for a time. We might not have imagined this possibility until recently. If federal funding for health care, housing, and community development is slashed, and if the resulting pressure on states and local governments pushes our disinvested communities even more to the fringe of policy priorities, then what do we do? In fact, we have learned a lot about how planners and practitioners can jointly manage community development work with equitable outcomes. The history of the last thirty-five years in Cleveland has taught us that it's a matter of focus, coalition building, truth-telling, and political will.

\section{REFERENCES}

Cleveland City Planning Commission. 1975. Cleveland Policy Planning Report. Cleveland: City Planning Commission.

Cunningham, Randy. 2007. Democratizing Cleveland: The Rise and Fall of Community Organizing in Cleveland, Ohio 1975-1985. Cleveland: Arambala Press.

Cuyahoga Earned Income Tax Credit (EITC), The. n.d. Cuyahoga County, Ohio (website). https://www.refundohio.org.

Feran, T. 2014. "Housing First Opens Newest Apartments in Work to End Homelessness," Plain Dealer, September 16.

Krumholz, N. 1997. "The Provision of Affordable Housing in Cleveland.” In Affordable Housing and Urban Redevelopment in the United States, edited by Willem van Vliet. Thousand Oaks: Sage.

Marr, C., Chye-Ching Huang, Arloc Sherman, and Brandon DuBot. 2015. "EITC and Tax Credit Promote Work, Reduce Poverty, and Support Children's Development, Research Finds," Center of Budget and Policy Priorities, October 1.

McDermott, M. 2004. "National Intermediaries and Local Community Development Corporation Networks: A View from Cleveland," Journal of Urban Affairs 26 (2): 171-76.

McQuarrie, M., and Norman Krumholz. 2011. "Institutionalized Social Skill and the Rise of Mediating Organizations in Urban Governance: The Case of the Cleveland Housing Network," Housing Policy Debate 21 (3): 421-42.

Simon, Mary, E. 2003. Celebrating 25 Years. Cleveland: The Maxine Goodman Levin College of Urban Affairs, Cleveland State University.

Swanstrom, T. 1985. The Crisis of Growth Politics: Cleveland, Kucinich, and the Challenge of Urban Populism. Philadelphia: Temple University Press.

Yin, J. 1998. "The Community Development Industry System: A Case Study of Politics and Institutions in Cleveland, 1967-1997," Journal of Urban Affairs 20 (2): 137-57. 